\title{
Influence of Pulsing Biocides on Vase Life of Cut Roses (Rosa hybrida L.)
}

\author{
Shimeles Tilahun ${ }^{1 *}$, Jeong Cheon Soon ${ }^{2}$ and Park Do Su ${ }^{2}$ \\ ${ }^{1}$ Department of Horticulture and Plant Science, Collge of Agriculture and Veterinary Medicine, \\ Jimma University, P.O. Box: 307, Jimma, Ethiopia \\ ${ }^{2}$ Department of Horticulture, Kangwon National University, Chuncheon-200701, South Korea
}

\begin{tabular}{|c|c|}
\hline & Article Information \\
\hline \multirow{12}{*}{$\begin{array}{l}\text { The effects of pulsing solutions comprising biocides }\left(1 \mathrm{~g} \mathrm{Al} 2\left(\mathrm{SO}_{4}\right)_{3} \mathrm{I}-1,0.4 \mathrm{ml} \mathrm{HQS} \mathrm{I-1,} \text {, }\right. \\
\left.0.6 \mathrm{ml} \mathrm{NaOCl} \mathrm{l}-1,0.6 \mathrm{~g} \mathrm{Ca}(\mathrm{ClO})_{2} \mathrm{I}-1\right) \text {, and tap water as control) on the vase life of rose } \\
\text { (Rosa hybrida } \mathrm{L} \text {.) cut flower variety Upper Class which is Red colored intermediate } \\
\text { flower was evaluated in laboratory experiment. The pulsing treatments were arranged in } \\
\text { a CRD with four replications. The results depicted that treatments comprised NaOCl } \\
\text { and } \mathrm{HQS} \text { were able to prolong the vase life of the cut flower stalks up to } 15.80 \text { and } \\
15.40 \text { days respectively while } \mathrm{Al}_{2}\left(\mathrm{SO}_{4}\right)_{3} \text { did not offer statistically significant advantage } \\
\text { over the use of ordinary tap water. Spectrometric analysis on solution turbidity of the } \\
\text { vase solutions depicted the smallest value in cut flower stalks pulsed with NaOCl while } \\
\text { the highest values were recorded in water, which is an indication of more bacterial } \\
\text { proliferation or accumulation of plant exudates in the later cases. The amount of water } \\
\text { passed through } 5 \mathrm{~cm} \text { long excised stem sections was the highest in stalks pulsed with } \\
\mathrm{Ca}(\mathrm{ClO})_{2} \text { and NaOCl while the lowest was in those pulsed with } \mathrm{Al}_{2}\left(\mathrm{SO}_{4}\right)_{3} \text { and water. } \\
\text { Pulsing of the cut flower stalks with biocides also significantly increased vase solution } \\
\text { uptake, and total soluble solid during vase life. The results of the present study clearly } \\
\text { indicated significant improvement of the vase life of cut flower stalks by biocide pulsing } \\
\text { treatment especially NaOCl and } \mathrm{HQS} \text {. }\end{array}$} & Article History: \\
\hline & Received : 12-05-2015 \\
\hline & Revised : :13-09-2015 \\
\hline & Accepted : 18-09-2015 \\
\hline & Keywords: \\
\hline & Cut Flowers \\
\hline & Intermediate Rose \\
\hline & Hydraulic Conductance \\
\hline & Solution Uptake \\
\hline & Physiological Characteristics \\
\hline & ${ }^{*}$ Corresponding Author: \\
\hline & Shimeles Tilahun \\
\hline & E-mail: eyushim@gr \\
\hline ga University. All Righ & \\
\hline
\end{tabular}

\section{INTRODUCTION}

Rose, a universally celebrated flower, has been used as garden plant since the dawn of civilization. It belongs to family Rosaceae and Genus Rosa which contains more than 150 species and 1400 cultivars (Gault and Synge, 1971).

Roses are recognized as highly valuable for economic benefits being the best source of raw material to be used in agro-based industry especially in the cosmetics and perfumery. Additionally, roses play a vital role in the manufacturing of various products of medicinal and nutritional importance. However, a very peculiar aspect of rose production is to get the cut flowers, which greatly deals with the floricultural business (Butt, 2003).

In European countries, during winter season, snow and frost check the flower production and there is a need to modify the climate which will increase production cost. Contrarily, Ethiopia is fortunate to have all types of climates and can produce fresh flowers round the year with little efforts. There is a need to transport the flowers to long distances in an attractive condition which requires good preservative chemicals, transportation facilities and the use of suitable packing materials (EHPEA, 2008).
After harvesting, the cut flowers are literally cut off from their source of life which, of course, accelerates the flowers' ageing process. To increase vase life as long as possible, treatment at growers' phase is crucial; because, flowers take up about $80 \%$ of their water requirement within the first two hours after harvest (Roskam, 2010). Delaying the rate at which the quality of perishable commodities deteriorate and/or extending their natural appearance during vase life, may provide additional time for harvesting and delivering the crop to wholesalers and retailers, and ultimately to the consumers (Chapman and Austin-brown, 2007).

Under ordinary conditions, the flowers could be a source of beautification and attraction for only few days. Since most of the people like to enjoy the beauty and scenery of flowers for a longer period of time, keeping in view the socioeconomic value of flowers, there is a dire need to explore the possibilities of extending vase life.

Thus, the objectives of this research were to evaluate the effect of pulsing biocides on some physiological characteristics of fresh cut roses during their postharvest/ vase life and to identify the best pulsing biocide to extend vase life of roses. 
Shimeles Tilahun et alo,

\section{MATERIALS AND METHODS}

Site Description

The experiment was conducted at Hussain Al-Said Roses, Ethiopia. Olonkomi is located in Dendi woreda in the Oromia Region of Ethiopia at latitude of $9^{\circ} 0^{\prime} \mathrm{N}$, longitude of $38^{\circ} 15^{\prime} \mathrm{E}$, an altitude of 1586 m.a.s.l and about $60 \mathrm{~km}$ west of Addis Ababa, the capital city of Ethiopia. During the time of the experiment plants of Upper class were grown under greenhouse condition having an average day and night temperature of $20^{\circ} \mathrm{C}$.

\section{Treatments and Design}

Cuttings of Upper class rose variety were pulsed in biocides $\left(1 \mathrm{~g} \mathrm{Al}_{2}\left(\mathrm{SO}_{4}\right)_{3} \mathrm{I}^{-1}, 0.4 \mathrm{ml} \mathrm{HQS} \mathrm{I}^{-1}, 0.6 \mathrm{ml} \mathrm{NaOCl}{ }^{-1}\right.$, $\left.0.6 \mathrm{~g} \mathrm{Ca}(\mathrm{ClO})_{2} \mathrm{I}^{-1}\right)$ and tap water as control), with four replications in a completely randomized design (CRD). Each experimental unit consisted of six flower stalks. In studying the effect of the different pulsing solutions on the vase life of the cut flower stalks, the experiments were divided into two groups. The first group contained explicitly none destructive experiment while the second group contained destructive measurements. Evaluations were made by keeping the flower stalks in an evaluation room, at room condition (mean temperature of $21^{\circ} \mathrm{C}$ and $60 \% \mathrm{RH}$ ) with $12 \mathrm{~h}$ of photoperiod. The sources of irradiance for the room were cool-white fluorescent lamps. Harvesting was done early in the morning and the stems were kept in an upright position, in buckets partially filled with tap water. To simulate the practice exercised by the growers, they were kept in pre-cooling room $\left(8-10^{\circ} \mathrm{C}\right)$ before grading to remove greenhouse heat. Sorting and grading were done after two hours to choose flowers that fit for export purpose. Sorted and graded flowers were kept in cooling room $\left(2-4{ }^{\circ} \mathrm{C}\right)$ immediately after bunches were put in buckets partially filled with pulsing biocides $\left(1 \mathrm{~g} \mathrm{Al}_{2}\left(\mathrm{SO}_{4}\right)_{3} \mathrm{I}^{-1}, 0.4 \mathrm{ml} \mathrm{HQS} \mathrm{^{-1 }}, 0.6 \mathrm{ml} \mathrm{NaOCl} \mathrm{I}^{-1}, 0.6 \mathrm{~g}\right.$ $\left.\mathrm{Ca}(\mathrm{ClO})_{2} \mathrm{I}^{-1}\right)$ and tap water as a control. The pulsing biocide solution was prepared in water obtained from tap for all of the treatments. The $\mathrm{pH}$ of pulsing solution was adjusted to 3.5-4.5 with citric acid and for Aluminum sulfate with $\mathrm{KOH}$. The postharvest behavior of the flower stalks was studied during vase life study following the initial pulse treatment of 24 hours. The flower stalks were taken out from the cold room and all of the pulsing solutions were replaced with $500 \mathrm{ml}$ preservative vase solution that contained flower food (long life) at a concentration of $10 \mathrm{~g} \mathrm{I}^{-1}$.

\section{Statistical Analysis}

Significance tests were made by analysis of variance (ANOVA) using SAS procedure of version 9 (SAS institute, 2004). Mean comparisons were made using least significance difference (LSD).

\section{RESULTS}

\section{Flower Longevity}

The result presented in figure1 showed that longevity of cut flower stalks was significantly increased by pulsing treatment of biocides and preservative solution. The maximum vase life was observed in cut flower stalks pulsed with $600 \mathrm{mg} \mathrm{NaOCl} \mathrm{I}^{-1}$ followed by $0.4 \mathrm{ml} \mathrm{HQS} \mathrm{I}^{-1}$; and the lowest was observed in $\mathrm{Al}_{2}\left(\mathrm{SO}_{4}\right)_{3}$ pulsed and tap water treated flower stalks. The $\mathrm{Al}_{2}\left(\mathrm{SO}_{4}\right)_{3}$, which is a common biocide used in the Ethiopian cut flower industry, was not able to extend the vase life of cut flower stalks more than the control, treated with tap water.
Sci. Technol. Arts Res. J., July-Sep 2015, 4(3): 79-82

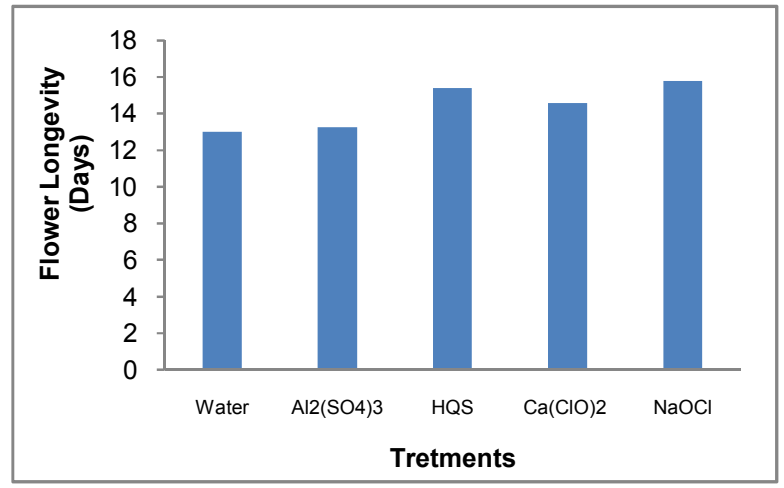

Figure 1: Effects of pulsing solutions on flower longevity of upper class rose cut flower stalks evaluated at room conditions

\section{Solution Absorbance}

Vase solution absorbance was significantly influenced by pulse treatment of the cut flower stalks (Figure 2). The highest vase solution absorbance values were recorded from treatment with tap water while the lowest vase solution absorbance values were recorded in $\mathrm{NaOCl}$ and HQS pulsing treatments.

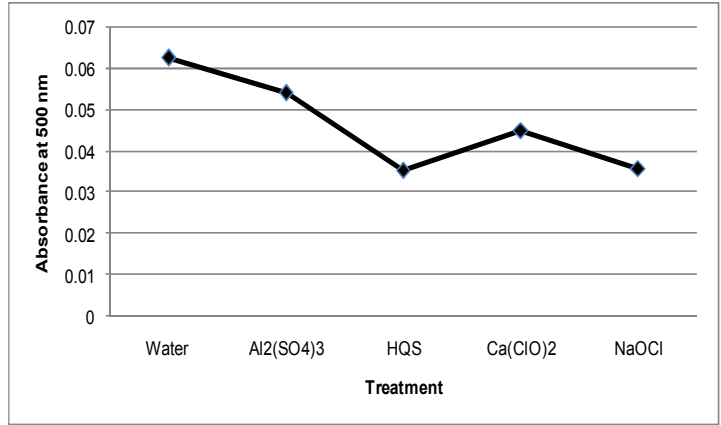

Figure 2: Effect of pulsing solutions on vase solution absorbance at $500 \mathrm{~nm}$

\section{Hydraulic Conductance}

The result presented in Table 1 showed a significant difference in the hydraulic conductance of the stem sections excised at $10-15 \mathrm{~cm}$ and $20-25 \mathrm{~cm}$ from the base of the cut flower stalks in pulsing treatments with biocides. However, no significant difference was recorded in the stem sections excised from $0-5 \mathrm{~cm}$ from the base. In stem sections excised at 10 to $15 \mathrm{~cm}$ the highest hydraulic conductance was recorded from $\mathrm{Ca}(\mathrm{ClO})_{2}$ treated stalks followed by $\mathrm{Al}_{2}(\mathrm{SO} 4)_{3}$ and $\mathrm{NaOCl}$ while the lowest was from tap water treated stalks. In the same manner, in stem sections excised at 20 to $25 \mathrm{~cm} ; \mathrm{NaOCl}$ and $\mathrm{Ca}(\mathrm{ClO})_{2}$ treated stalks showed significantly higher hydraulic conductance than the other treatments.

\section{Solution Uptake}

Addition of biocides in the pulsing/vase solution controls microbial proliferation, reduces vascular occlusion, and increases solution uptake.

\section{Total Soluble Solids (TSS)}

The amount of TSS in the petals was determined by squeezing the sap from the petals. Significant differences were observed in terms of petal TSS values among the different pulsing treatments throughout the sampling periods (Table 3 ). 
Table 1: Effects of pulsing solutions on vase hydraulic conductance of cut flower stalks at different distance from the base $(\mathrm{cm})$ evaluated at room conditions

\begin{tabular}{cccc}
\hline \multirow{2}{*}{ Treatments } & \multicolumn{3}{c}{$\begin{array}{c}\text { Hydraulic conductance }(\mathbf{m l}) \text { at a } \\
\text { distance from the base (cm) }\end{array}$} \\
\cline { 2 - 4 } & $\mathbf{0}$ to $\mathbf{5}$ & $\mathbf{1 0}$ to $\mathbf{1 5}$ & $\mathbf{2 0}$ to $\mathbf{2 5}$ \\
\hline Water & 0.41 & $0.57^{\mathrm{c}}$ & $1.28^{\mathrm{b}}$ \\
$\mathrm{Al}_{2}(\mathrm{SO} 4)_{3}$ & 0.48 & $0.82^{\mathrm{ab}}$ & $1.30^{\mathrm{b}}$ \\
$\mathrm{HQS}$ & 0.51 & $0.80^{\mathrm{b}}$ & $1.30^{\mathrm{b}}$ \\
$\mathrm{Ca}(\mathrm{ClO})_{2}$ & 0.47 & $0.94^{\mathrm{a}}$ & $1.67^{\mathrm{a}}$ \\
$\mathrm{NaOCl}$ & 0.46 & $0.81^{\mathrm{ab}}$ & $1.77^{\mathrm{a}}$ \\
\hline Significance & $\mathbf{N s}$ & $* * *$ & $* * *$ \\
SEM \pm & $\mathbf{0 . 0 3}$ & $\mathbf{0 . 0 4}$ & $\mathbf{0 . 0 7}$
\end{tabular}

$\mathrm{Ns},{ }^{* *}$ and ${ }^{* * *}$ indicate no significant $\mathrm{p}=0.05$ and significant at 0.01 and 0.001 probability level, respectively, SEM= standard error of the mean.

Table 2. Solution uptake of cut flower stalks as affected by pulsing solutions evaluated at different vase life stages and room conditions

\begin{tabular}{cccccc}
\hline \multirow{2}{*}{ Treatments } & \multicolumn{5}{c}{ Solution uptake in ml/day/g fresh weight } \\
& $\mathbf{1}$ & $\mathbf{4}$ & $\mathbf{7}$ & $\mathbf{1 0}$ & $\mathbf{1 3}$ \\
\cline { 2 - 6 } & $0.4358^{\mathrm{b}}$ & $0.2525^{\mathrm{c}}$ & $0.2642^{\mathrm{b}}$ & $0.2233^{\mathrm{c}}$ & $0.217^{\mathrm{c}}$ \\
Water & 0.5592 & 0.3258 & 0.3058 & 0.2667 & $0.247^{\mathrm{b}}$ \\
$\mathrm{Al}_{2}(\mathrm{SO} 4)_{3}$ & $0.4625^{\mathrm{ab}}$ & $0.2867^{\mathrm{ab}}$ & $0.3117^{\mathrm{a}}$ & $0.2433^{\mathrm{ab}}$ & $0.259^{\mathrm{a}}$ \\
$\mathrm{HQS}$ & $0.4417^{\mathrm{b}}$ & $0.2792^{\mathrm{b}}$ & $0.2500^{\mathrm{bc}}$ & $0.2192^{\mathrm{bc}}$ & $0.2025^{\mathrm{c}}$ \\
$\mathrm{Ca}(\mathrm{ClO})_{2}$ & $0.4158^{\mathrm{bc}}$ & $0.2750^{\mathrm{b}}$ & $0.2875^{\mathrm{ab}}$ & $0.2192^{\mathrm{bc}}$ & $0.2433^{\mathrm{b}}$ \\
$\mathrm{NaOCl}$ & $* * *$ & $* * *$ & $* * *$ & $* * *$ & $* * *$ \\
\hline Significance level & $\mathbf{0 . 0 2 4 3}$ & $\mathbf{0 . 0 1 5 0}$ & $\mathbf{0 . 0 1 2 7}$ & $\mathbf{0 . 0 1 2 2}$ & $\mathbf{0 . 0 1 1 7}$ \\
\hline SEM $\mathbf{E}$ & $\mathbf{0 . 0 2 0}$
\end{tabular}

Table 3: Effect of pulsing solutions on total soluble solid in petals evaluated at room conditions.

\begin{tabular}{cccc}
\hline \multirow{2}{*}{ Treatments } & \multicolumn{3}{c}{ Total soluble solid (\%) } \\
& $\mathbf{3}$ & $\mathbf{7}$ & $\mathbf{1 1}$ \\
\cline { 2 - 4 } & $7.28^{\mathrm{ab}}$ & $7.78^{\mathrm{c}}$ & $10.50^{\mathrm{ab}}$ \\
\hline Water & $7.06^{\mathrm{ab}}$ & $8.50^{\mathrm{ab}}$ & $11.44^{\mathrm{a}}$ \\
$\mathrm{Al}_{2}(\mathrm{SO} 4)_{3}$ & $6.11^{\mathrm{c}}$ & $8.94^{\mathrm{a}}$ & $11.50^{\mathrm{a}}$ \\
$\mathrm{HQS}$ & $6.06^{\mathrm{c}}$ & $8.44^{\mathrm{ab}}$ & $11.33^{\mathrm{a}}$ \\
$\mathrm{Ca}(\mathrm{ClO})_{2}$ & $6.56 \mathrm{~b}^{\mathrm{c}}$ & $7.44^{\mathrm{c}}$ & $10.33^{\mathrm{b}}$ \\
$\mathrm{NaOCl}$ & $* * *$ & $* * *$ & $*$ \\
\hline Significance level & $\mathbf{0 . 2 6}$ & $\mathbf{0 . 1 7}$ & $\mathbf{0 . 3 1}$ \\
SEM \pm & & &
\end{tabular}

** and *** indicate significant at $\mathrm{p}=0.01$ and 0.001 probability level, respectively, SEM= standard error of the mean

\section{DISCUSSION}

Louband and van Doorn (2004) reported stem blockage in rose (Rosa hybrida cv. Red One) mainly due to living bacteria and their decay products. Van Doorn et al. (1990) also reported a positive correlation between abundance of bacteria and the decrease in hydraulic conductance of the stem. Many germicides such as HQS, $\mathrm{AgNO}_{3}$ and $\mathrm{Al}_{2}\left(\mathrm{SO}_{4}\right)_{3}$ have been shown to inhibit bacterial growth in cut rose stems (van Doorn, 1997). The significant reduction in vase solution absorbance in pulsing treatments of $\mathrm{NaOCl}$ and $\mathrm{HQS}$ could be due to the antimicrobial effect of these biocides. HQS is a wellknown germicide although it is toxic to some rose cultivars leading to shortening of their vase life (Ichimura et al., 2006). Knee (2000) also reported a reduction in solution absorbance (0.057) of 'Classy' roses treated with HQC.
These observations confirm that pulsing treatments with $\mathrm{NaOCl}$ and $\mathrm{HQS}$ were the most effective in reducing microbial proliferation and also resulted in increased clearness of the vase solution. The result clearly indicated that the addition of $\mathrm{Al}_{2}\left(\mathrm{SO}_{4}\right)_{3}$ did not offer advantage over the use of ordinary tap water as Reid et al. (2001) also reported the same finding.. Knee (2000), also reported high values of vase solution absorbance in the absence of biocide and in $\mathrm{Al}_{2}\left(\mathrm{SO}_{4}\right)_{3}$ solutions. In the present study, it was observed that addition of the most effective biocides: $\mathrm{NaOCl}, \mathrm{HQS}$ and $\mathrm{Ca}(\mathrm{ClO})_{2}$ into the pulsing solution was associated with longer flower life and low vase solution absorbance.

The result appears to support the view that vascular occlusion is due to mainly bacterial proliferation. Pulsing 
Shimeles Tilahun et al.,

of cut flower stalks with germicides such as HQS (Ichimura et al., 2003) inhibited bacterial proliferation and maintained the hydraulic conductance of the stem segments. The hydraulic conductance of cut rose flower stalks decreases with time after harvest, and this decrease is associated with bacterial proliferation (van Doorn et al., 1989; Ichimura et al., 2003). According to Van Doorn et al. (1989), the development of vascular occlusion was correlated with the growth of bacteria at the cut surface and inside the stem.

In the present study, the lowest hydraulic conductance was observed in $0-5 \mathrm{~cm}$ excised stem and there is an increase in hydraulic conductance as the height of stem cut increases. This could be attributed to the blockage due to bacterial growth at the stem end. The finding was supported by van Doorn et al. (1989) who reported the lowest hydraulic conductance value in the basal stem segments for Sonia, Ilona, Motrea, Jack Frost, and Mercedes rose cultivars.

Knee (2000) observed that for most of the effective biocides added in vase solutions, longer flower life and increased solution uptake were associated with low resistance to water flow and vase solution absorbance. In the present study too, increased solution uptake by cut flower stalks was associated with extension of their vase life except $\mathrm{Al}_{2}(\mathrm{SO} 4)_{3}$. The observations might be as a result of $\left(\mathrm{Al}_{2}\left(\mathrm{SO}_{4}\right)_{3}\right.$ being toxic to the cut flower stalks, which was also witnessed from scorching of petals and abscission of leaves.

\section{CONCLUSIONS}

Significant differences were observed among the pulsing solutions with respect to promoting the vase life of the cut flower stalks. The results depicted that treatments comprised $\mathrm{NaOCl}$ and $\mathrm{HQS}$ were able to prolong the vase life of the cut flower stalks up to 15.80 and 15.40 days, respectively, while the lowest vase life of 13 days was observed in those flowers pulsed with tap water. The presence of $\mathrm{Al}_{2}\left(\mathrm{SO}_{4}\right)_{3}$ in the pulsing solutions significantly reduced the vase life of the cut flower stalks, and the other parameters considered. The results of the present study clearly indicated significant improvement of the vase life of Upper class cut flower stalks by biocide pulsing treatment especially $\mathrm{NaOCl}$ and $\mathrm{HQS}$.

\section{Conflict of Interest}

Authors declared no conflict of interest.

\section{REFERENCES}

Butt, S.J. (2003). A Review on Prolonging the Vase Life of Roses. Pakistan Rose Annual. National Rose Society pp. 49-53.

Chamani, A.K., Joyce, D.C., Irving, D.E., Zamani, Z.A., Mostofi, Y. and Kafi, M. (2005). Ethylene and antiethylene treatment effects on cut 'First Red' rose. Journal of Applied Horticulture 1:3-7.

Chapman, K.D., and Austin-brown. S. (2007). Methods for extending the freshness of cut flowers, ornamental trees,
Sci. Technol. Arts Res. J., July-Sep 2015, 4(3): 79-82

and plant cuttings. Http://www.freepatentsonline.com. Accessed on June 2010.

EHPEA. (2008). Flowers and ornamentals. http://www.ethiomarket.com/eic Accessed on June, 2010.

Gault, S.M. and Synge, P.M. (1971). The Dictionary of Roses in Color .Ebury press and Michael Joseph, Hagul, 11p.

Ichimura, K., Taguch, M. and Norikoshi. R. (2006). Extension of the vase life in cut roses by treatment with glucose, isothiazolinonic germicide, citric acid and aluminum sulphate solution. Japan Agricultural Research Quaterly 40: 263-269.

Ichimura, K., Kawabata, Y., Kishimoto, M., Goto, R. and Yamada, K. (2003). Shortage of soluble carbohydrates is largely responsible for short vase life of cut 'Sonia' rose flowers. Journal of the Japanese Society for Horticulture Science 72: 292-298.

Ichimura, K., Kawabata, Y., Kishimoto, M., Goto, R. and Yamada, K. (2002). Variation with the cultivar in the vase life of cut Rose flowers. Bulletin of the National Institute of Florida Science 2: 9-20.

Knee, M. (2000). Selection of biocides for use in floral preservatives. Postharvest Biology and Technology 18: 227-234.

Louband, M., van Doorn, W.G. (2004). Wound-induced and bacteria-induced xylem blockage in rose, Astilbe, and Viburnum. Postharvest Biology and Technology 32: 281288.

Pompodakis, N.E. and Joyce. D.C. (2003). Abscisic acid analogue effects on vase life and leaf crisping of cut Baccara rose. Australian Journal of Experimental Agriculture 43: 425-428

Reid, M.S., Dodge, L., Celikel, F.G. and Cho, M. (2001). Sucrose enhances the postharvest quality of cut flowers of Eustoma grandiflorum (raf.) shinn. Acta Horticulture 543: 305-315.

Rogers, M.N. (1973). An historical and critical review of postharvest physiology research on cut flowers. Horticulture Science 8:189-194.

Roskam (2010). Postharvest treatment; Roskam Young Plants. http://www.Roskam-youngplants.com/florissant news. htm. Accessed on June 2010.

SAS Inst. Inc. (2004). Statistical analysis software ${ }^{\circledR}$. Cary, in.NC: SAS Institute inc. USA

Van Doorn, W.G. (1990). Aspiration of air at the cut surface of rose stems and its effect on the uptake of water. Journal of Physiology 137:160-164.

Van Doorn, W.G. (1997). Water relations of cut flowers Horticulture Review 18:1-85.

Van Doorn, W.G. (2001). Role of soluble carbohydrates in flower senescence: a survey. Horticulture Review 543: 179-183.

Van Doorn, W.G., Schurer, K. and De Witte, Y. (1989). Role of endogenous bacteria in vascular blockage of cut rose. Journal of Plant Physiology 134: 375-381. 